\title{
STUDY OF REPERCUSSIONS OF SOCIAL MEDIA ON COLLEGE TEACHER USING STATISTICAL TECHINQUES
}

\author{
Prakash S. Chougule ${ }^{1}$ \\ Associate Professor, Rajarshi Chhatrapati Shahu College Kolhapur-416005. (MS), India
}

Tejaswi S. Kurane ${ }^{2}$

Assistant Professor, Rajarshi Chhatrapati Shahu College Kolhapur-416005. (MS), India

Suresh V. Patil ${ }^{3}$

Associate Professor, Rajarshi Chhatrapati Shahu College Kolhapur-416005. (MS), India

Hritik R. Chavan ${ }^{4}$

Research Student, Rajarshi Chhatrapati Shahu College Kolhapur-416005. (MS), India

Ajinkya C. More ${ }^{5}$

Research Student, Rajarshi Chhatrapati Shahu College Kolhapur-416005. (MS), India

Ajit S. Sutar ${ }^{6}$

Research Student, Rajarshi Chhatrapati Shahu College Kolhapur-416005. (MS), India

Vishakha V. Patil ${ }^{7}$

Research Student, Rajarshi Chhatrapati Shahu College Kolhapur-416005. (MS), India

Article DOI: https://doi.org/10.36713/epra5050

\begin{abstract}
The internet and social media provide students with a range of academic benefits and opportunities to enhance their learning process. The main goal of this research is to examine the impact of using the social media on the academic performance. The new social networks, such as Instagram, Facebook, Twitter, etc., can affect the behavior and academic performance of the college teachers, therefore the selected sample as college teachers in rural and urban area. The analysis carried out through some statistical techniques and made some meaningful concluding remarks.

KEYWORDS: Graphical Representation, Chi-square Test, Proportion Test, Level of significance.
\end{abstract}

\section{INTRODUCTION}

Today's Universities have well-developed social media strategies, and use a suite of social media tools for various purposes including internal and external communications, recruitment, sharing research findings, and highlighting exciting student initiatives. Social media tools and technology are also making their way into the classroom, although the 2013 Pearson Report indicates that its use in teaching lags behind other uses, and that "faculty are much more willing to embrace social media in their personal lives than they are to use it for professional or teaching purposes". However, active proponents are quick to relate how these tools increase student engagement and have a positive influence on teaching and learning. Is there any substance behind these claims? Is there any evidence that social media has a useful place in the classroom?

It's becoming increasingly clear that social media is commonly used in the University context. 
The majority of faculty $(78.9 \%)$ feels that digital communication has increased their communication with students Blogs and wikis are the tools most commonly used in classrooms, followed by podcasts, LinkedIn, Facebook and Twitter. There are some detailed, quantitative case studies that have tested the value of specific tools in the context of the classroom environment in higher education. The authors list the following benefits of using Twitter in higher education:

- Helped with general communication about the course (e.g., details about assignments, class announcements, or due dates)

- Improved contact among students and between students and the instructor Increased cooperation among students

- Promoted active learning whereby students' experiences (inside and outside the classroom) were more easily linked to course materials

- Helped to created a strong learning community among students

- Increased participation by students, including those who would otherwise be intimidated by the lecture-hall environment
- Quick Internet searches will yield many similar statements, and support the idea of using social media tools in teaching and learning.

Universities certainly need to develop guidelines for the use of social media tools in the classroom. In addition, instructors must be savvy with social media technologies, etiquette, and 'terms of use' before introducing them into the classroom context.

\section{METHODOLOGY}

We collect the primary data from 4 colleges in Kolhapur district and classify this data into two areas i.e. Rural and Urban. We have collected primary data by questionnaires prepared and information is collected from respondent.

\section{STATISTICAL TOOLS}

$>$ Graphical Representation

$>$ Test for Proportion

$>$ Test for chi-square for independence of Attributes

\section{Graphical Representation}

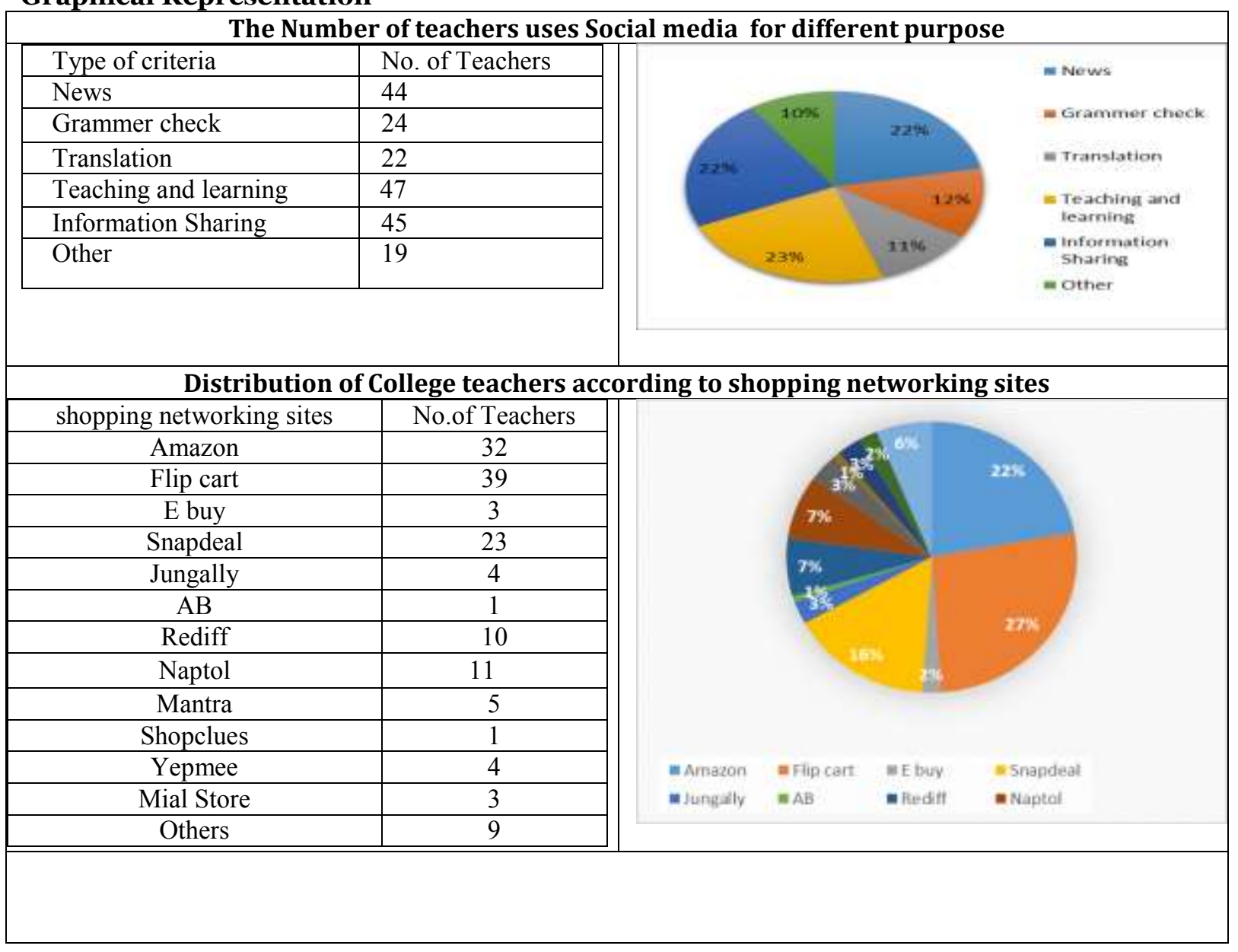




\begin{tabular}{|c|c|c|c|}
\hline \multicolumn{4}{|c|}{ Distribution of different tools used for uses social media of College Teachers } \\
\hline Type of Media & No. of Teachers & \multirow{5}{*}{$45 \%$} & \multirow{5}{*}{$\begin{array}{l}=\text { Compute } \\
=\text { Tab } \\
=\text { Mobile }\end{array}$} \\
\hline Computer & 43 & & \\
\hline $\mathrm{Tab}$ & 7 & & \\
\hline Mobile & 48 & & \\
\hline Other & 9 & & \\
\hline \multicolumn{4}{|c|}{ Distribution of various purpose of WhatsApp uses of college teachers } \\
\hline Purpose of uses & No. of Teachers & \multirow{3}{*}{\multicolumn{2}{|c|}{ Use of Whatsapp in teaching }} \\
\hline Notes & 26 & & \\
\hline Jokes & 16 & & \\
\hline Video of teaching subject & 10 & \multirow{9}{*}{$\begin{array}{l}=\text { Notes } \\
=\text { Video of teaching subject } \\
=\text { For function }\end{array}$} & \\
\hline Important Mail & 41 & & \\
\hline For function & 25 & & \\
\hline Exam & 10 & & \\
\hline Group discussion & 24 & & \\
\hline Massage & 28 & & \multirow{4}{*}{$\begin{array}{l}\text { = Jokes } \\
=\text { Important Mail } \\
\text { = Exam }\end{array}$} \\
\hline Solving problem & 21 & & \\
\hline other & 11 & & \\
\hline & & & \\
\hline
\end{tabular}

\section{Tests of independence for data from rural and urban}

$\mathrm{H}_{0}$ : Availability of students training in college for the awareness of Social Media is independent on area $\mathrm{H}_{1}$ : Availability of students training in college for the awareness of Social Media is independent on area

$$
\chi_{\text {cal }}^{2}=4.0887 \quad \chi_{t a b}^{2}=3.841
$$

\section{Tests of proportion of users}

$H_{0}: p_{1}=p_{2}$ i. e. The proportion of users is insignificant.

$H_{1}: p_{1} \neq p_{2}$ i. e. The proportion of users is significant.

$$
Z_{c a l}=0.0108 \quad Z_{t a b}=1.96
$$

\section{CONCLUSION}

Through this research, the researcher focused on the impact of social media on academic performance. The maximum teacher used social media for teaching and learning about 3-5 Hrs. in week. Also, teachers are used E-mail for teaching process and used pendrive for storing the information. Most of the teachers used Flip-cart networking sites for purchasing teaching instruments on mobile and computer. WhatsApp is more preferable for important massage and notes. The Availability of students training in college for the awareness of social media is dependent on area. The proportion of social media users in rural and urban is same. So, finally we conclude that, the social media in teaching practice is helpful for effective teaching.

\section{REFERENCE}

1. Al. Alwani Abdulkareem, Information Technology Integration in Higher Education International Journal of Emerging Technologies in Learning, 9(6), pp. 32-36.

2. Bates Tony, The Continuing Evolution of ict Capacity, 2008, 24(01) https://Www.Tonybates.Ca/Wpcontent/Uploads/2 008/07/Farrell.Pdf

3. Blanka Klimova et. al. A Social Networks in Education, 2015, 25(1), http://web.a.ebscohost.com/ehost/pdfviewer/pdfvi ewer? sid $=a$

4. Chatti, M., Amine, J. and Quix, C. Connectivism in International Journal of Learning Technology 5, 1, pp. 80-99, 2010.

5. Creswell, J. W. (2007). Qualitative enquiry and research design: Choosing among five Approaches.

6. Dewing, M. (2010). Social Media: An Introduction (Vol. 1). Library of Parliament.

7. Ellison, N. B. (2007). Social network sites: Definition, history, and scholarship. Journal of Computer Mediated Communication, 13(1), 210230.

8. Gurcan, H. I. (2015). Contribution of Social Media to the Students' Academic Development. International Journal of Information and Education Technology, 5(12), 965. 